\title{
Regulatory Science and Social Movements: The Trial Against the Use of Pesticides in Argentina
}

\author{
Florencia Arancibia*
}

In August 2012 a transgenic soy producer and a pesticide spraying pilot were sentenced to three years of conditional prison for potential pollution and harm to public health in Cordoba, Argentina. This was the first case of pesticide pollution judged by Criminal Law in Latin America and the verdict became a turning point in the struggle to regulate pesticides in Argentina. The trial was initiated by the movement "Madres de Ituzaingó" from a neighborhood surrounded by transgenic soy fields sprayed with glyphosate-based herbicides (to which GM seeds are resistant). They found an increase in cancer rates and made the nexus between their illnesses and glyphosate exposure. In this way, they challenged official "regulatory science", which classifies glyphosate as a product of low toxicity, commercialized and used without restriction. Through in-depth interviews and ethnographic observation, I found that the ruling was an outcome of interconnected actions which included typical forms of protest, the production of "undone science", as well as other actions involving expertise. [Article copies available for a fee from The Transformative Studies Institute. E-mail address: journal@transformativestudies.org http://www.transformativestudies.org (C2016 by The Transformative Studies Institute. All rights reserved.]

KEYWORDS: Pesticides, Pollution, Social Movements, Regulatory Science, Undone-Science.

\footnotetext{
* Florencia Arancibia, Ph.D., is a post-doctoral researcher for the National and Scientific Research Council in Argentina. Her research areas include social movements, environmental controversies, risk governance, and social studies of science and technology. Her dissertation focused on new social movements in the arena of "regulatory science", and novel relationships between activism and expertise. She has focused on campaigns for restricting the use of pesticides in GM soy producing Argentina and has published on this topic in various journals including Technology in Society. She holds a Ph.D. in Sociology from SUNY Stony Brook and was a Fulbright scholar and Inter-American Foundation fellow. Address correspondence to: Florencia Arancibia, National and Scientific Research Council, Argentina; Ciudad Autonoma de Buenos Aires, Argentina; e-mail: farancibia@fund-cenit.org.ar.
} 